\title{
Competent synthesis of biaryl analogs via asymmetric Suzuki-Miyaura cross-coupling for the development of anti-inflammatory and analgesic agents
}

\author{
H. D. Gurupadaswamy ${ }^{1} \cdot$ V. Lakshmi Ranganatha ${ }^{2} \cdot$ Ramith Ramu $^{3} \cdot$ Shashank M. Patil $^{3} \cdot$ Shaukath Ara Khanum $^{1}$ (D)
}

Received: 9 July 2021 / Accepted: 15 November 2021 / Published online: 4 January 2022

(c) Iranian Chemical Society 2021

\begin{abstract}
Based on the core structure of diflunisal drug, herein, we report a resembling series of biaryl analogs (3a-j) containing halogens, nitro, and methoxy substituents. They were designed and synthesized via a Suzuki-Miyaura cross-coupling reaction using $\mathrm{Pd}(\mathrm{OH})_{2}$ as a catalyst at a temperature of $65^{\circ} \mathrm{C}$ with an intent to obtain improved and safer anti-inflammatory and analgesic agents. Suzuki-Miyaura transformation is the most significant among the cross-coupling reactions since its practical advantages include the commercially available low toxic reagents, mild reaction conditions, and functional group compatibility. On the other hand, a few conditions can be used to cross-couple aryl boronic acids or esters with aryl halides, especially 2-benzyl halides. Because of this, a novel Suzuki-Miyaura protocol is investigated that facilitates the selective conversion of halo aromatics, with an emphasis on the reaction to convert substituted bromobenzene to conjugated biphenyls. Finally, the obtained biaryl analogs $(\mathbf{3 a}-\mathbf{j})$ were tested for in vitro and in vivo anti-inflammatory and analgesic applications. The results showed that compound $\mathbf{3 b}$ performed better than the standard drug with $\mathrm{IC}_{50}$ values comparable to that of the standard drug for COX-1 and COX-2 inhibition. Finally, molecular docking tests for the effective compound were carried out.
\end{abstract}

Keywords Suzuki-Miyaura $\cdot$ Cross-coupling $\cdot$ Biaryl analogs $\cdot$ Anti-inflammatory $\cdot$ Analgesic activity $\cdot$ Docking study

H. D. Gurupadaswamy and Shaukath Ara Khanum have contributed equally to this work.

Shaukath Ara Khanum shaukathara@yahoo.co.in

1 Department of Chemistry, Yuvaraja's College, University of Mysore, Mysuru, Karnataka 570005, India

2 Department of Chemistry, The National Institute of Engineering, Manandavadi Road, Mysuru, Karnataka 570008, India

3 Department of Biotechnology and Bioinformatics, Faculty of Life Sciences, JSS Academy of Higher Education and Research, Mysuru, Karnataka 570015, India 


\section{Introduction}

The body naturally counters infection and tissue damage through various defense mechanisms. In case of conditions such as chronic asthma, rheumatoid, and osteoarthritis, the inflammatory cascade is responsible for various conditions such as multiple sclerosis, inflammatory bowel diseases and psoriasis, diabetic nephropathy, tumor initiation, and malignant progression [1]. In 1971, Merck Sharp and Dohme developed a diflunisal anti-inflammatory molecule that is a salicylic acid derivative with analgesic and antiinflammatory properties [2]. Like all nonsteroidal antiinflammatory (NSAIDs) drugs, diflunisal acts by inhibiting the production of prostaglandins [3], the hormones that are involved in inflammation and pain. Diflunisal also possesses an antipyretic effect, but this is not a recommended use of the drug [4]. In continuation to our earlier work on antiinflammatory research [5-8], we have synthesized similar biaryl analogs that possess a high structural resemblance to the diflunisal molecule. These biaryl analogs were synthesized by Suzuki-Miyaura cross-couple aryl boronic acids or esters with aryl halides, especially 2-benzyl halides, emphasizing the reaction to convert the substituted bromobenzene to conjugated biphenyls [9].

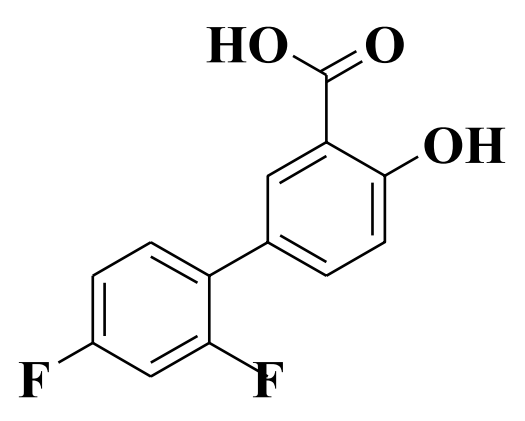

Diflunisal experimental circumstances. As an extensive structural motif, biaryls are habitually found in natural products [12], liquid crystalline materials [13], organic semiconducting materials, and biologically and pharmacologically active species [14].

Regularly, the most common technique for performing transformations of organoboron compounds or organic halides or triflates is palladium-catalyzed cross-coupling reactions $[15,16]$. Among the main reactions in organic chemistry, $\mathrm{C}-\mathrm{C}$ bond formation via a cross-coupling reaction catalyzed by transition metals is undoubtedly the most important reactions and has been exploited widely in the recent years. Palladium, the most widely used metal, enables the synthesis of complex and functionalized organic molecules, and its chemistry possesses different exciting sides such as heterogeneous and homogeneous catalysis under mild experimental conditions compatible with many functional groups [17].

Numerous palladium-containing catalysts are presently reported for the catalysis of the Suzuki reaction. Palladium catalysts have several disadvantages including their high cost and the potential for fatal contamination of pharmaceutical products. As a result, many researchers have looked into<smiles>[R4]c1ccccc1-c1cc([R4])c([R15])c([R2])c1[R1]</smiles>

2-Benzyl halides
The carbon-carbon bond formation reaction is an essential transformation due to the enormous significance of the resulting compounds in organic, pharmaceutical, and polymer chemistry [10]. Therefore, there has been a tremendous interest in developing competent methods for such a conversion, and a well-known method constitutes the Suzuki-Miyaura cross-coupling reaction. This reaction has led to the development of various powerful and versatile methodologies. Among them, Suzuki couplings [11] represent one of the most attractive approaches for $\mathrm{C}\left(\mathrm{sp}^{2}\right)-\mathrm{C}\left(\mathrm{sp}^{2}\right)$ bond-forming biaryl syntheses and, in the meantime, may not essentially require passive palladium composites that can be easily separated at ultralow catalyst loadings [18], wherein solvents like acetone, toluene, THF, acetonitrile, and DMF, which are slightly more expensive, deadly, and difficult to recycle, are the most often employed solvents for these coupling processes [19]. Suzuki-Miyaura reactions in water are a hot topic of research, although most substrates and catalysts are insoluble in water [20-22]. Ethanol is a non-toxic and environmentally friendly alternative renewable solvent that is used for various extraction processes as well [23]. Notably, the number of organic substrates soluble in this solvent is substantially more comprehensive than water. 
Table 1 In vitro inhibition of COX-1 and COX-2 enzymes by compounds $3 \mathrm{a}-\mathrm{j}$

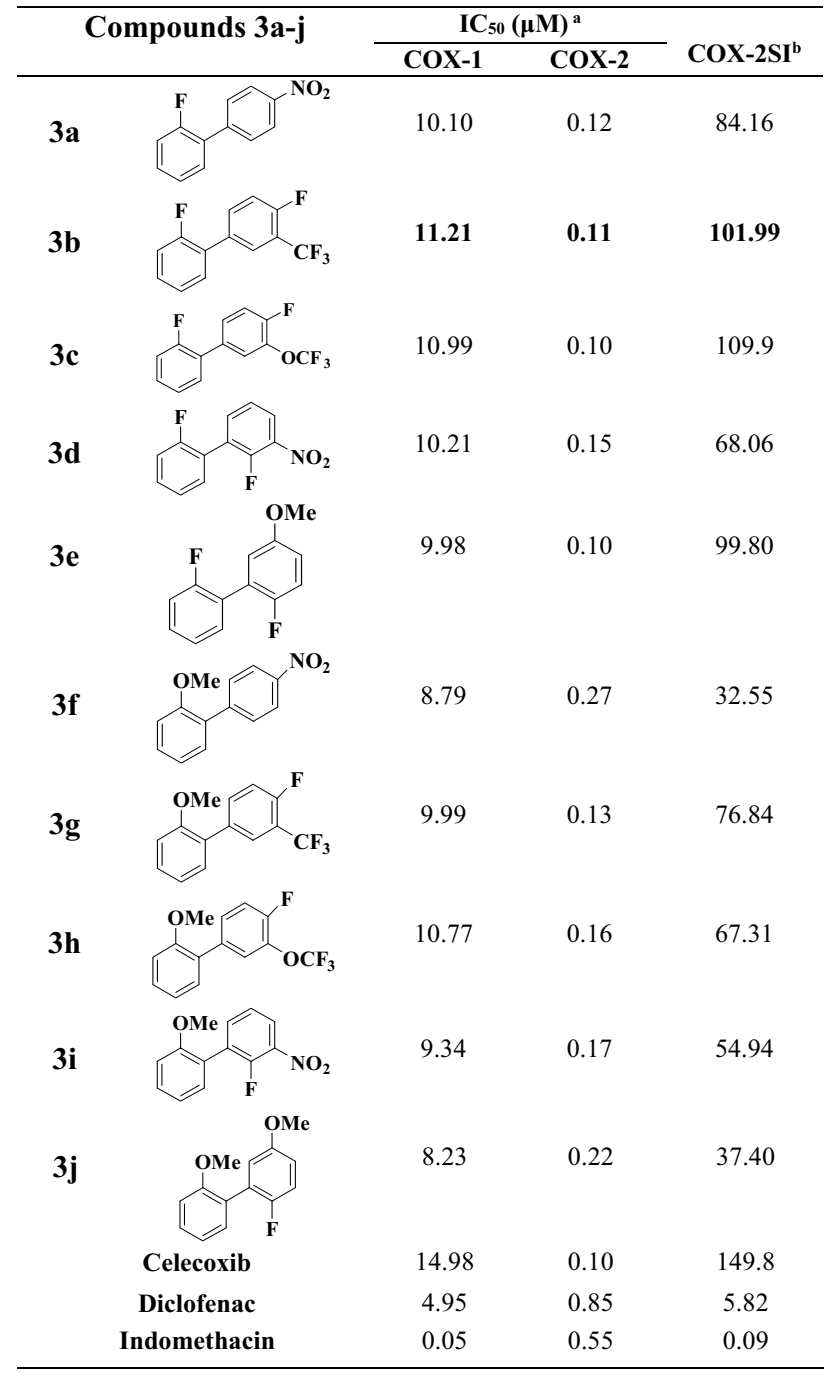

Bold values indicate the more potent compound

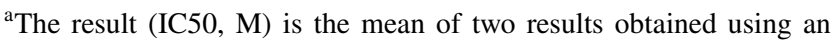
ovine COX-1/COX-2 assay and is the in vitro concentration of synthesized compound that inhibits COX-1 and COX-2 enzymes by $50 \%$. The standard deviation is ten percent of the mean value.

${ }^{\mathrm{b}}$ The in vitro COX-2 selectivity index (COX-1 $\left.\mathrm{IC}_{50} / \mathrm{COX}-2 \mathrm{IC}_{50}\right)$

Keeping this in view, in continuation to our earlier work, herein, we report an efficient and ecofriendly technique for the Suzuki-Miyaura coupling between aryl halides and aryl boronic acid catalyzed by $\mathrm{Pd}(\mathrm{OH})_{2}$, and all the synthesized compounds were tested for in vitro and in vivo anti-inflammatory and analgesic applications with in Silico studies.

\section{Results and discussion}

\section{Chemistry}

The synthesis of biaryl analogs via Suzuki coupling reaction of haloaryl with various phenylboronic acids has been reported [24]. As a result, more progress has been made in using the potential of Suzuki coupling reactions for the synthesis of a variety of biaryl derivatives [10]. In summary, the Suzuki reactions of substituted phenylboronic acids ( $1 \mathrm{a}-\mathrm{b})$ with various substituted bromobenzene to yield corresponding biaryls are described in this paper $(3 \mathbf{a}-\mathbf{j})$. To generate improved yields, the best reaction conditions were potassium phosphate as a base, $\mathrm{Pd}(\mathrm{OH}) 2$ as a catalyst, and a temperature of $65^{\circ} \mathrm{C}$. The Suzuki reactions of 1a-b with equimolar substituted aryl-boronic acids 2a-e resulted in biphenyl derivatives $\mathbf{3 a}-\mathbf{j}$ in a rational yield (Table 1). When ethanol and water were utilized as solvents instead of toluene, greater yields of freshly synthesized biphenyl derivatives $3 a-j$ were obtained. The final yield of biphenyl derivatives depends on the type of solvent utilized in the synthesis. The best yield was obtained with a 1:3 (water/ethanol) solvent mixture consistent with earlier reports using the solvents such as toluene or $\mathrm{DMF}^{24}$. While these reactions were performed in a 3:1 ethanol/water solvent system, an increase in water volume decreased the product yield, perhaps due to the low solubility of reactants in a larger quantity of water, ethanol, and potassium phosphate. However, the combination showed to be efficient and environmentally friendly, and the reaction did depend on temperature since the yield did not impact at both $65{ }^{\circ} \mathrm{C}$ and $50{ }^{\circ} \mathrm{C}$.

Furthermore, the synthesized compounds were wellcharacterized by appropriate methods such as spectroscopic evaluation viz., IR, ${ }^{1} \mathrm{H}$ NMR, and elemental analysis. Data obtained were found to be in good agreement with the calculated values of the projected structures. The newly obtained compounds were subjected to preliminary testing for their anti-inflammatory and analgesic activity. Among all the tested compounds, compound $\mathbf{3 b}$ evolved as the most potent anti-inflammatory and analgesic agent.

\section{Pharmacology}

\section{COX-1 and COX-2 in vitro inhibitory activity}

The peroxidase activity of the synthesized compounds 3a-j was measured using a colorimetric enzyme immune test to determine their potency to inhibit the bovine COX-1 and COX-2 enzymes. The $\mathrm{IC}_{50}$ values of the synthesized compounds and reference compounds such as celecoxib, diclofenac, and indomethacin were then measured. As presented in Table 1, COX-2 selectivity index (SI) values were also computed as follows $\left[\mathrm{IC}_{50}(\mathrm{COX}-1) / \mathrm{IC} 50(\mathrm{COX}-\right.$ $2)]$. The title compounds $3 \mathbf{a}-\mathbf{j}\left(\mathrm{IC}_{50}=8.23-11.21 \mu \mathrm{M}\right)$ showed poor COX-1 inhibition in colorimetric experiments when compared to the selective COX-1 inhibitor (indomethacin, $\left.\mathrm{IC}_{50}=0.05 \mu \mathrm{M}\right)$ and the nonselective COX-1 
Table 2 Anti-inflammatory activity of compounds $3 \mathrm{a}-\mathrm{j}$

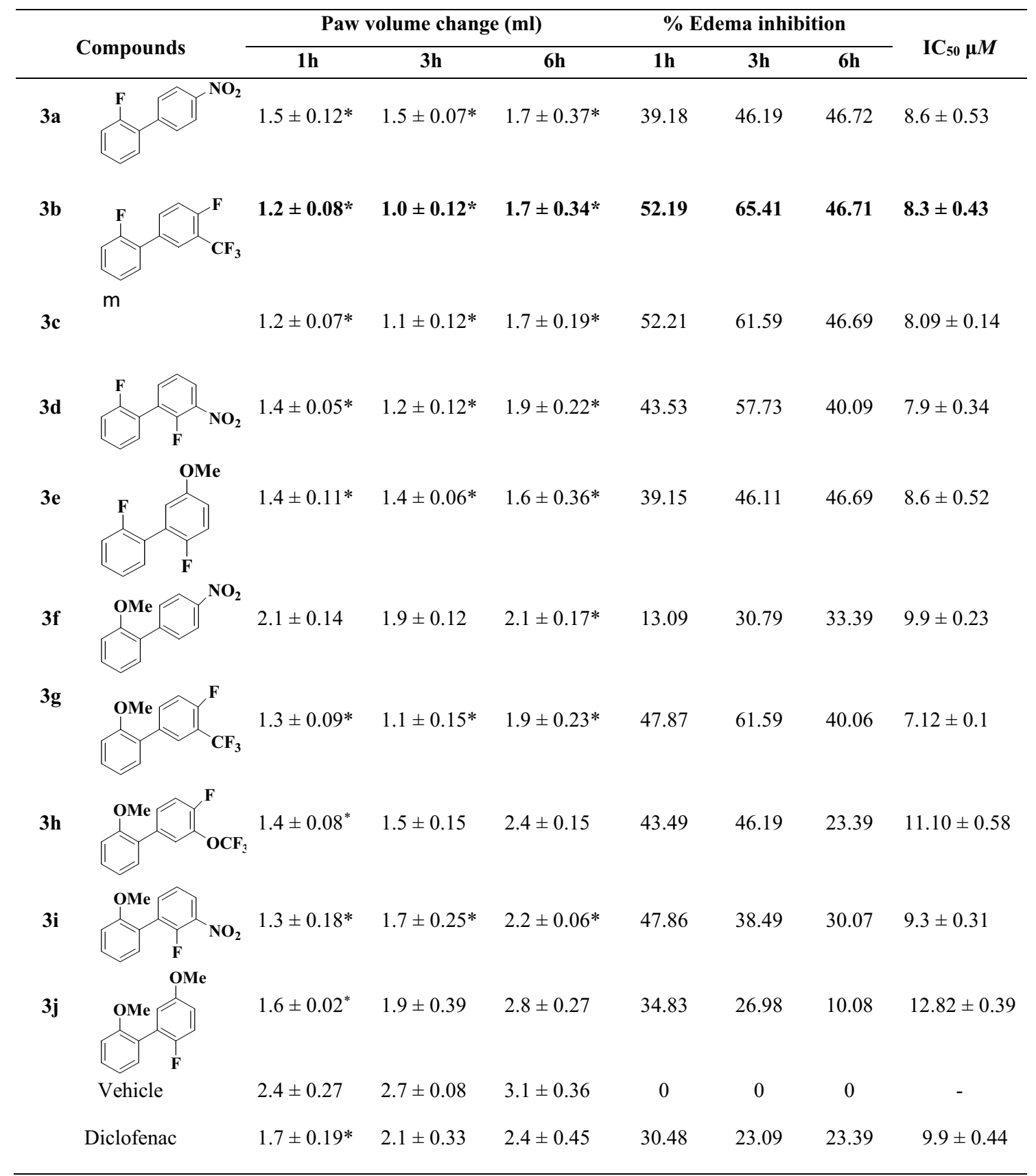

Values are means $\pm \operatorname{SEM}(n=3-4)$

Bold values indicate the more potent compound

*Significantly different from the normal control group at $p<0.05$

inhibitor (diclofenac, $\mathrm{IC}_{50}=4.95 \mu \mathrm{M}$ ). Furthermore, when compared to the selective COX-2 inhibitors celecoxib $\left(\mathrm{IC}_{50}=0.10 \mu \mathrm{M}\right)$ and diclofenac $\left(\mathrm{IC}_{50}=0.85 \mu \mathrm{M}\right)$, the title compounds $3 \mathrm{a}-\mathrm{j}$ showed adequate $\mathrm{COX}-2$ inhibition $\left(\mathrm{IC}_{50}=0.1-0.27 \mu \mathrm{M}\right)$. Compounds $\mathbf{3 a}, \mathbf{3 b}, \mathbf{3 c}, \mathbf{3 d}, \mathbf{3 e}$, and $\mathbf{3} \mathbf{g}$ in the series $\mathbf{3 a}-\mathbf{j}$ showed a significant COX-2 inhibition $\left(\mathrm{IC}_{50}=0.10-0.13 \mu \mathrm{M}\right)$ comparable with that of celecoxib, whereas compounds $\mathbf{3 f}, \mathbf{3} \mathbf{h}, \mathbf{3 i}$, and $\mathbf{3 j}$ had less potency toward COX-2 inhibition. COX-2SI compounds with electron-withdrawing groups such as $\mathbf{3 b}$ and 3c, which had more fluoro groups on both rings, had the highest SI values ( $\mathrm{SI}=101.99$ and 109.9 , respectively). The remaining compounds $\mathbf{3 a}$ and $\mathbf{3 d}-\mathbf{j}$ in the same series $(\mathrm{SI}=84.16,68.06,99.80,32.55,76.84,67.31$, 54.94, and 37.40, respectively) had moderate COX-2SI values as reported in Table 1. 
Table 3 ompounds $3 a-j$ showed the analgesic effect on the acetic acid-induced writhing test

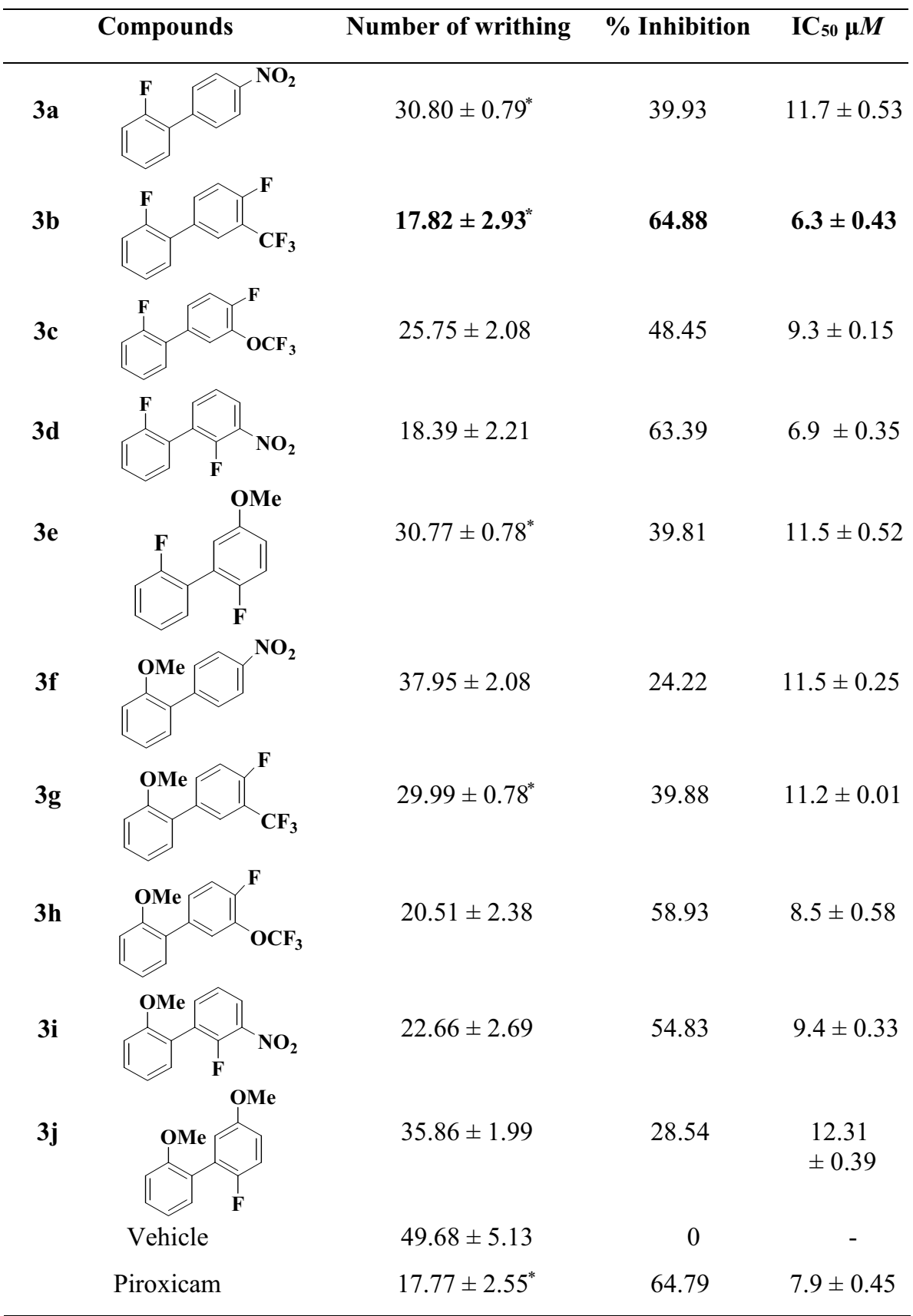

Data represent the mean value \pm SE of four mice per group. Drugs were, s.c., administered $30 \mathrm{~min}$ before testing. Statistical comparisons are made between the control group, and synthesized compounds treated group and denoted by $p<0.05$

Bold values indicate the more potent compound

*Significantly different from the normal control group at $p<0.05$

\section{Structure-activity relationship (SAR)}

Inflammation is a self-protective response of the body that encourages physiological adaptations to minimize tissue damage and remove pathogenic infections [25]. Biaryl analogs are well-known for biologically essential molecules against various pathological conditions, including anticancer and anti-inflammatory applications.
The current investigation involves a single-step synthesis of a combination of two substituted bioactive aromatic rings for its use as anti-inflammatory pharmacophores. The title compounds 3a-j have a fundamental backbone of diflunisal pharmacophores structurally. Tables 1, 2, 3 and 4 display the IC50 values for the synthesized compounds. Compound $\mathbf{3 b}$ appears to have two electron-withdrawing fluoro groups and $\mathrm{CF}_{3}$ group in the ortho position, referring to the table. 
Table 4 Compounds $3 \mathrm{a}-\mathrm{j}$ showed the analgesic effect on thermal pain induced by a hot plate technique

\begin{tabular}{|c|c|c|c|c|c|c|c|}
\hline & \multirow{2}{*}{ Compounds } & \multirow{2}{*}{ Basal } & \multicolumn{2}{|c|}{$1 \mathrm{~h}$} & \multicolumn{2}{|c|}{$2 \mathrm{~h}$} & \multirow{2}{*}{$\mathrm{IC}_{50} \boldsymbol{\mu} M$} \\
\hline & & & $\begin{array}{l}\text { Latency } \\
\text { time (s)* }\end{array}$ & $\begin{array}{c}\% \\
\text { Latency } \\
\text { change }\end{array}$ & $\begin{array}{c}\text { Latency } \\
\text { time } \\
(\mathbf{s})^{*} \\
\end{array}$ & $\begin{array}{c}\% \\
\text { Latency } \\
\text { Change } \\
\end{array}$ & \\
\hline $3 \mathbf{a}$ & & $19 \pm 6.8$ & $28 \pm 1.4^{*}$ & 51.00 & $20 \pm 2.2 *$ & 47.18 & $9.1 \pm 0.43$ \\
\hline $3 b$ & & $14 \pm 3.5$ & $26 \pm 1.2 *$ & 93.33 & $23 \pm 6.4 *$ & 58.19 & $7.3 \pm 0.34$ \\
\hline $3 c$ & & $20 \pm 3.8$ & $29 \pm 2.5^{*}$ & 48.37 & $27 \pm 3.9^{*}$ & 37.86 & $8.2 \pm 0.13$ \\
\hline 3d & & $15 \pm 3.9$ & $27 \pm 1.7^{*}$ & 86.74 & $28 \pm 2.9 *$ & 51.06 & $8.9 \pm 0.35$ \\
\hline $3 e$ & & $18 \pm 6.9$ & $27 \pm 1.3^{*}$ & 50.05 & $20 \pm 2.2^{*}$ & 47.19 & $8.9 \pm 0.40$ \\
\hline $3 f$ & & $16 \pm 4.5$ & $18 \pm 2.22$ & 14.37 & $17 \pm 1.7$ & 07.69 & $20.9 \pm 0.24$ \\
\hline $3 g$ & & $19 \pm 3.8$ & $28 \pm 2.4^{*}$ & 51.11 & $26 \pm 3.8^{*}$ & 39.89 & $9.5 \pm 0.03$ \\
\hline $3 \mathbf{h}$ & & $16 \pm 3.9$ & $23 \pm 3.82$ & 47.68 & $23 \pm 6.9$ & 47.69 & $10.2 \pm 0.37$ \\
\hline $3 \mathbf{i}$ & & $20 \pm 2.2$ & $28 \pm 1.2^{*}$ & 43.15 & $20 \pm 2.2^{*}$ & 47.18 & $9.3 \pm 0.54$ \\
\hline $3 \mathbf{j}$ & & $20 \pm 3.5$ & $28 \pm 4.6^{*}$ & 43.14 & $27 \pm 4.8^{*}$ & 37.89 & $12.2 \pm 0.39$ \\
\hline & Saline & $19 \pm 5.2$ & $19 \pm 5.64$ & 0 & $16 \pm 1.3$ & 0 & - \\
\hline & Piroxicam & $16 \pm 5.3$ & $28 \pm 2.3^{*}$ & 81.18 & $27 \pm 2.5^{*}$ & 74.37 & $6.9 \pm 0.47$ \\
\hline
\end{tabular}

Values are means \pm SD of four mice per group. Statistical comparisons between basal and post-drug values were analyzed for statistical significance using a one-way ANOVA test denoted by $p<0.05$

Bold values indicate the more potent compound

*Significantly different from the normal control group at $p<0.05$

In comparison with the standard, these functional groups located at particular positions are accountable for such a spectacular biological activity. Other compounds having different substituents at different positions of the benzene ring, on the other hand, have not demonstrated substantial activity. SAR of these compounds suggests that the position and type of substituents on the benzene ring of biaryl derivatives in compounds $\mathbf{3 a}-\mathbf{j}$ are important for activity based on 
the current investigation. In this regard, compound $\mathbf{3 b}$ was chosen as the lead molecule due to its high SAR compared to other analogs.

\section{In vivo anti-inflammatory activity of compounds $3 a-j$}

The in vivo anti-inflammatory activity of the title compounds $\mathbf{3 a}-\mathbf{j}$ was measured using a standard formalininduced rat paw edema experiment with diclofenac as a standard drug. The inflammation was induced in the rat paw through subcutaneous formalin injection and the pawvolume changes (\% edema inhibition), after 1,3 , and $6 \mathrm{~h}$ from the time of onset of inflammation, the paw-volume change (percent edema inhibition) owing to the treatment with compounds $\mathbf{3 a}-\mathbf{j}$, and the standard diclofenac $(10 \mathrm{mg} /$ $\mathrm{kg}$ ) was detected (Table 2). When compared to the standard chemical diclofenac, the findings showed a wide range of anti-inflammatory activity. Compared with the results for diclofenac, compound $\mathbf{3 b}$ from the series $\mathbf{3 a}-\mathbf{j}$ demonstrated a higher anti-inflammatory efficacy after $1 \mathrm{~h}$, whereas the remaining compounds in the same family showed moderate action, with $23.39 \%$ edema inhibition (Table 2). In a nutshell, the anti-inflammatory activity of the synthesized compounds showed that varied substitutions at carbon-carbon bridged biaryl pharmacophores resulted in active antiinflammatory activity. These compounds may exert their anti-inflammatory effects by inhibiting the production and release of inflammatory mediators such as polypeptide kinins and prostaglandins (Fig. 1).
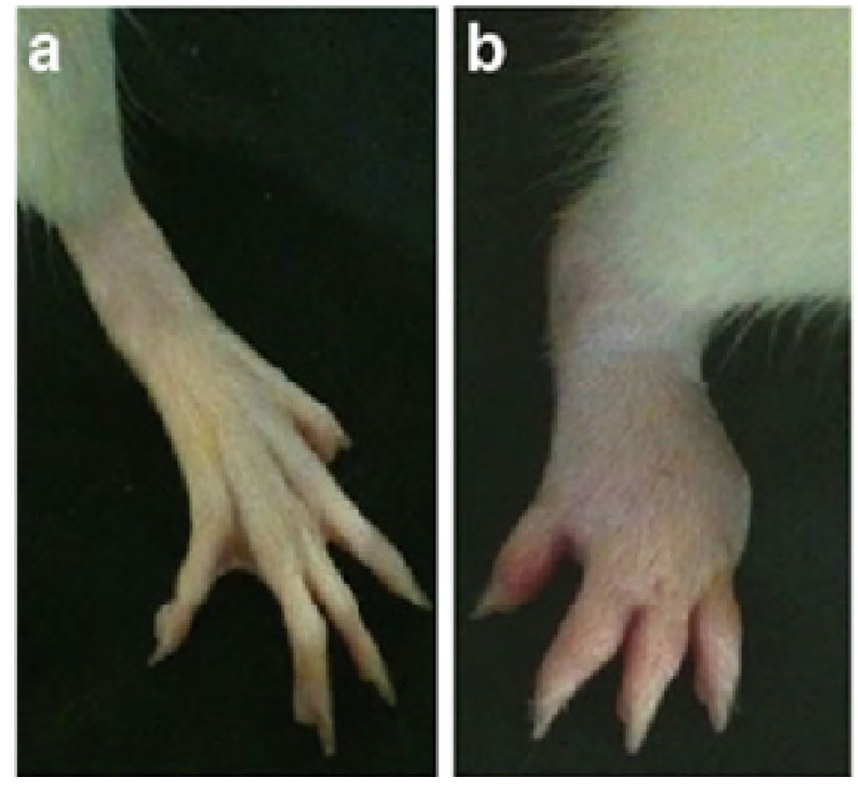

Fig. 1 Effect of compound 3b on carrageenan-induced paw edema in mice. Typical representative macroscopic photographs of the paw from the Normal, carrageenan + Saline, carrageenan + compound $\mathbf{3 b}$
Table 5 Docking score of ligands on COX-1 and COX-2

\begin{tabular}{lllll}
\hline Entry & Protein & Total score & Crash score* & Polar score $^{\wedge}$ \\
\hline Ligand & COX-1 & 7.2831 & -0.6713 & 0.4513 \\
& COX-2 & 7.6341 & -1.7610 & 0.8434 \\
\hline
\end{tabular}

*Crash score: revealing the inappropriate penetration into the binding site

${ }^{\wedge}$ Polar score: reports the polar region of the ligands

\section{Analgesic activity of compound $3 a-j$}

The analgesic activity of the synthesized compounds $\mathbf{3 a}-\mathbf{j}$ was determined using two methods: the acetic acid-induced writhing test and the hot plate latency test.

\section{Acetic acid-induced writhing test}

The acetic acid-induced writhing response method was used to assess anti-nociception. By limiting the release of endogenous mediators with nonsteroidal anti-inflammatory medications, intraperitoneal injection of acetic acid generated central nociception as well as peripheral actions. The title compounds 3a-j have revealed a wide range of analgesic effects in this analysis. In comparison with the vehicle-treated mice, the analgesic effect of compound $\mathbf{3 b}$ (64.88\% inhibition) was considerable and comparable to that of standard piroxicam (64.79\% inhibition) against acetic acid-induced writhing behavior (Table 3). On the other hand, the remaining compounds in the series dramatically
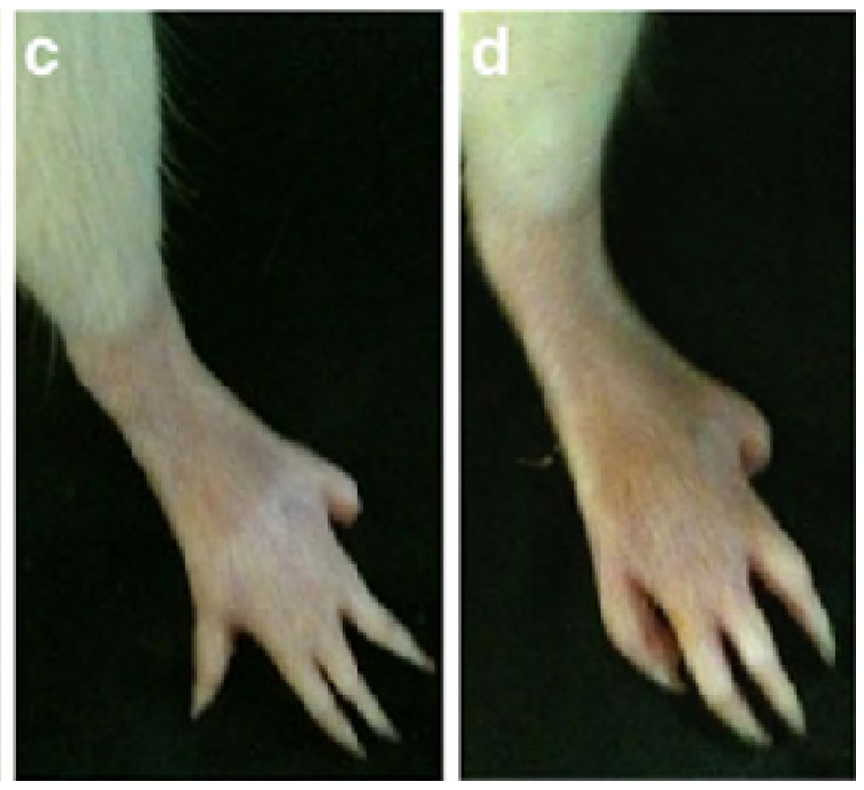

and carrageenan + Indomethacin, a: Normal, b: Negative control, $\mathbf{c}$ : compound $\mathbf{3 b}$, and $\mathbf{d}$ : positive control 


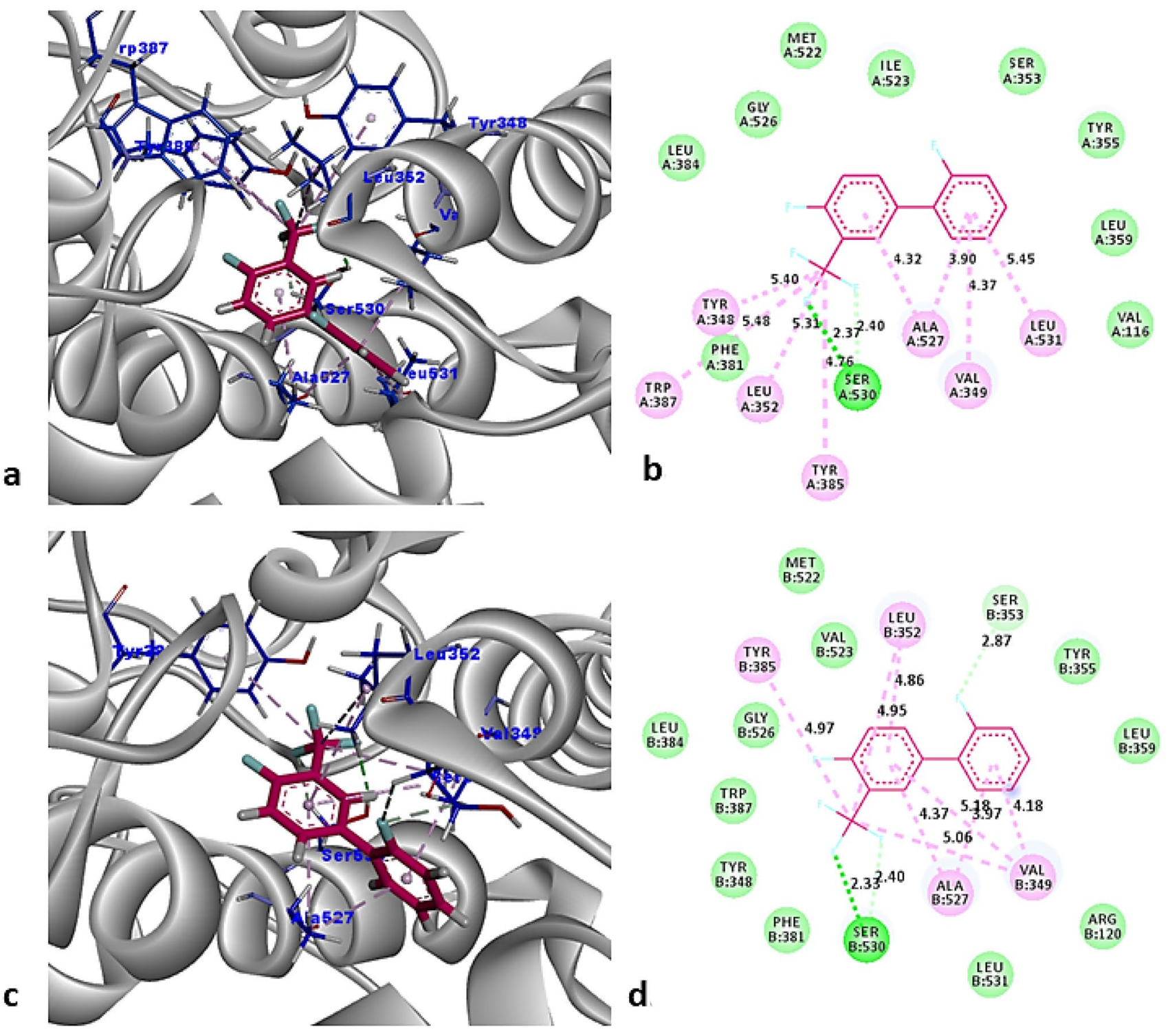

Fig. 2 Three-dimensional and two-dimensional representation of ligand bound to COX-1 (a and b) and COX-2 (c \& d)

reduced acetic acid-induced writhing in mice. According to SAR, the efficacy of compound $\mathbf{3 b}$ may be attributed to the presence of two fluoro groups in the biaryl rings, with one $-\mathrm{CF}_{3}$ group.

\section{Hot plate latency test}

In this experiment, the competence of the synthesized compounds $\mathbf{3 a}-\mathbf{j}$ for increasing the latency to pain evaluated by thermal treatment suggests that these compounds have some potential analgesic activity, which agrees with previous reports by Williamson and Koster et al. In contrast to the basal values, oral treatment of the compounds $3 \mathrm{a}-\mathrm{j}$ increased the latency time. Compound $\mathbf{3 b}$ revealed a 58.19-93.33 percent increase in pain threshold after $1 \mathrm{~h}$ in this study.
Surprisingly, compound $3 \mathrm{~b}$ had more powerful central analgesic action than the conventional piroxicam after $1 \mathrm{~h}$ of testing $(81.18 \%$, Table 4$)$. These findings revealed that the analgesic and anti-inflammatory activities of the synthesized compounds $\mathbf{3 a}-\mathbf{j}$ have a striking similarity.

\section{Docking studies: docking studies of lead compound 3b}

A molecular docking study fundamentally defines the binding modes of ligand interaction at the active site of the receptor [26]. In our study, the active compounds exhibiting notable activity were subjected to docking studies to assess their interaction with the inflammatory proteins COX-1 and COX-2, and the results are shown in 


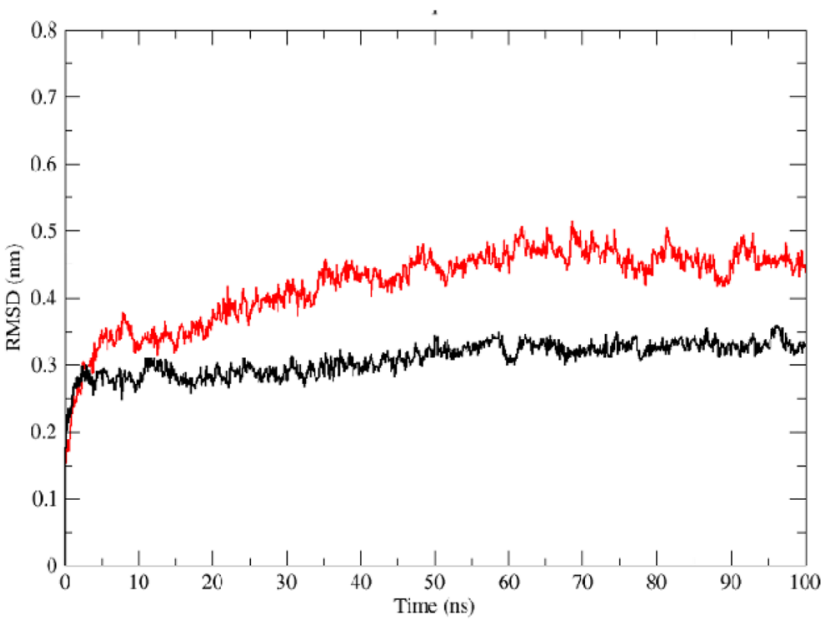

a

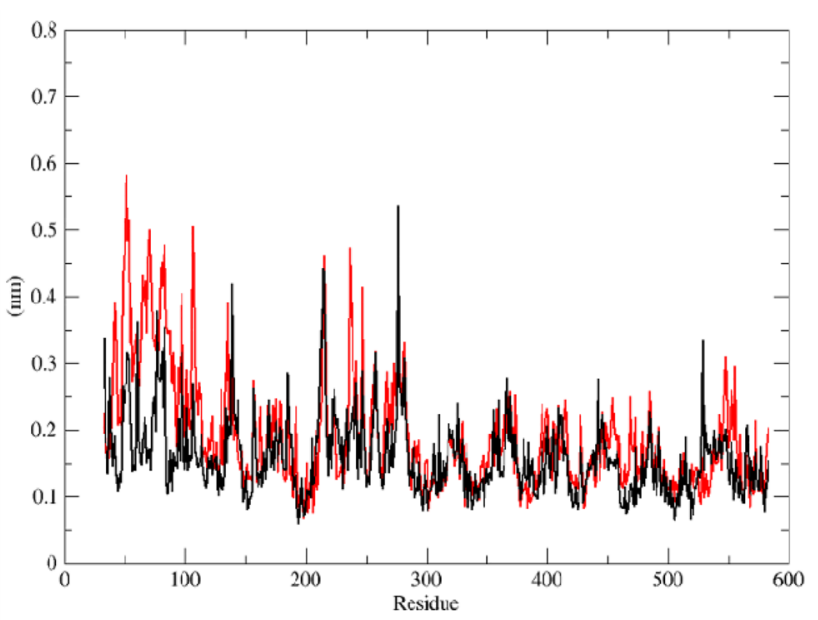

b

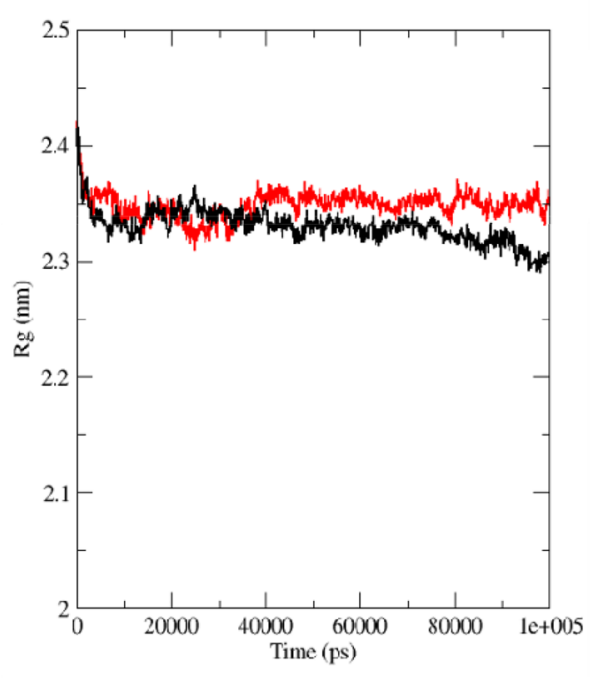

C

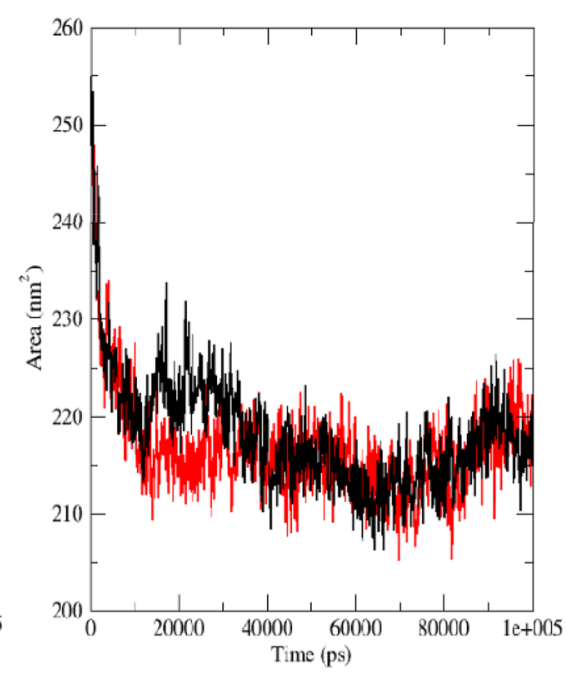

d

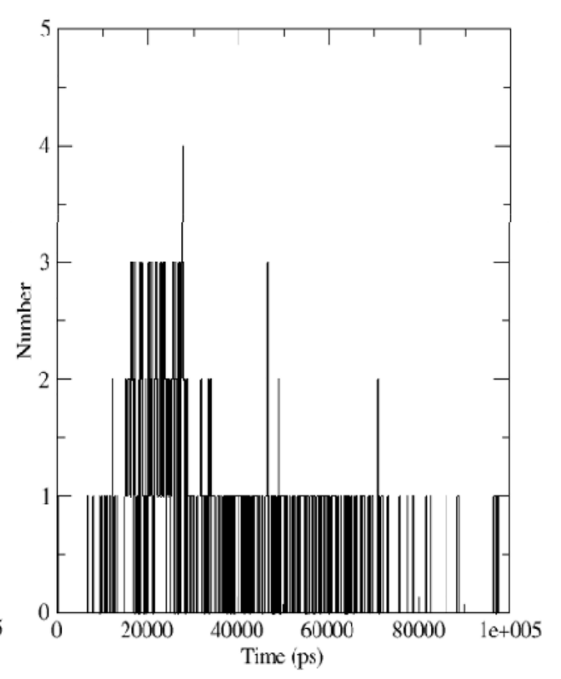

e
Fig. 3 Analysis of RMSD, RMSF, $R_{\mathrm{g}}$, SASA, and number of hydrogen bonds of COX-1 (protein) (PDB: 1EQG) with ligand complex of $\mathbf{3 b}$ at 100 numbers. a Time evolution of backbone RMSD of the COX-1 protein alone and with ligand complex structures. b Residuewise average RMSF plot of protein and ligand. (C) Radius of gyration $(R g)$ of the protein backbone in its free and complex form over the

Table 5. The binding interactions with the compounds revealed that almost all the compounds were interacting with alanine, valine, leucine, and threonine (Fig. 2a-d).

\section{Molecular dynamic simulation study}

In addition to docking, time-dependent molecular dynamic (MD) simulation studies were carried out to describe the dynamics of the protein-ligand complex under a solvated condition, following the previous studies conducted by the authors [27]. Hence, the best active designed ligands were entire simulation time. The ordinate is $R_{\mathrm{g}}(\mathrm{nm})$, and the abscissa is the time (ps) interval. d SASA is indicated, where ordinate is SASA $(\mathrm{nm})$, and the abscissa is time (ps). e Hydrogen bonds occurring over the time of simulation between protein and ligand. Note: Red: COX-1 protein; Black: COX-1 protein and $\mathbf{3 b}$ ligand complex

taken to map the stability of complexes under simulated conditions. Simulation study provides the analysis of root-meansquare deviation (RMSD), root-mean-square fluctuation (RMSF), solvent accessible surface area (SASA), radius of gyration $\left(R_{\mathrm{g}}\right)$, and the number of hydrogen bonds maintained throughout the simulation time and variation of protein secondary structures pattern with that of their complexes. Independently, in this study, within a span of $100 \mathrm{~ns}$, six simulations were performed with the native protein alone and in complex with its ligand. This study is undertaken to understand the stability and binding affinities in a time-bound 


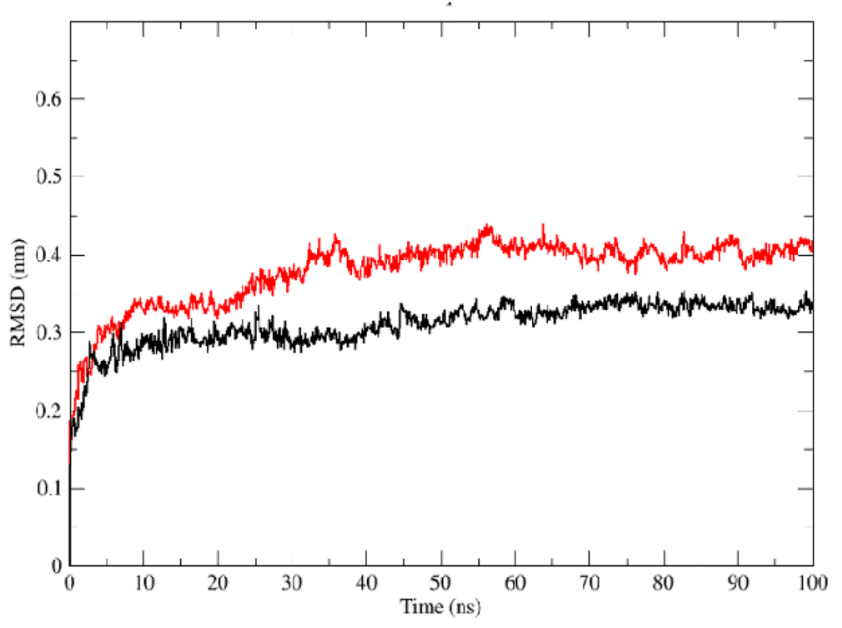

a

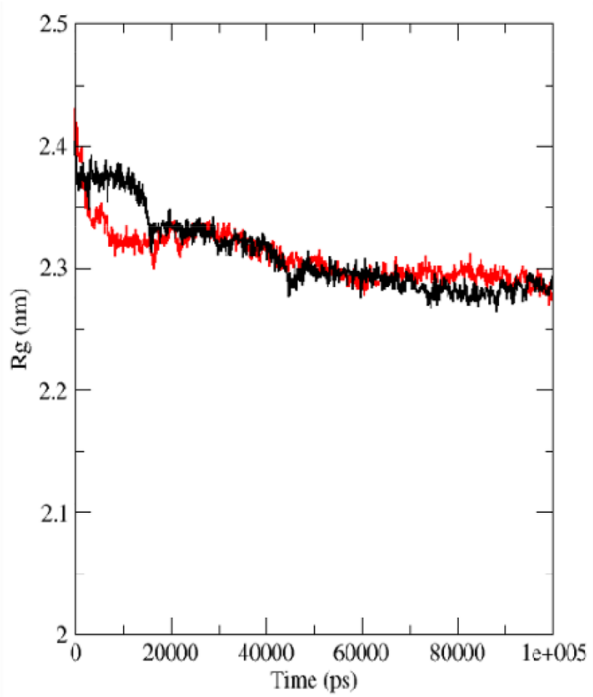

C

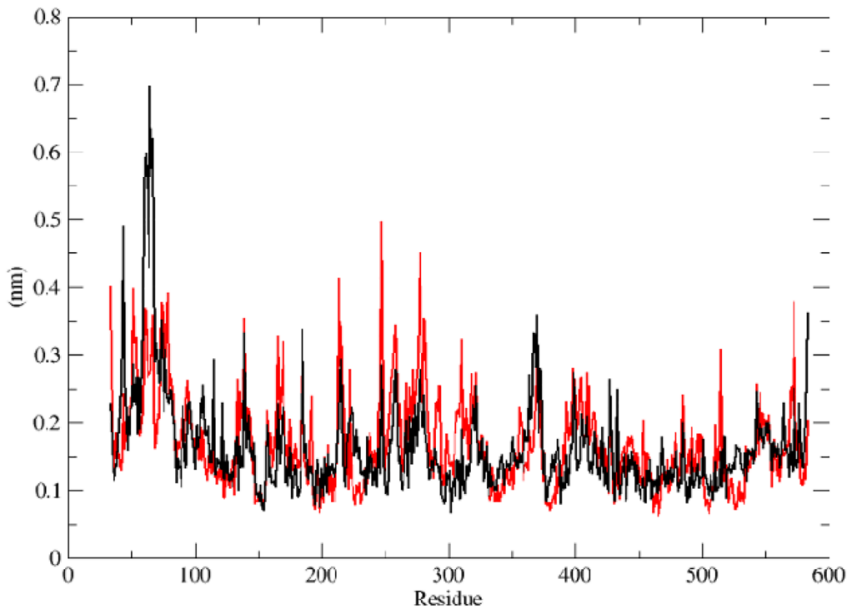

b
Fig. 4 Analysis of RMSD, RMSF, $R_{\mathrm{g}}$, SASA, and number of hydrogen bonds of COX-2 (protein) (PDB: 4M11) with ligand complex of $\mathbf{3 b}$ at 100 numbers. a Time evolution of backbone RMSD of the COX-2 protein alone and with ligand complex structures. b Residuewise average RMSF plot of protein and ligand. $\mathbf{c}$ Radius of gyration $\left(R_{\mathrm{g}}\right)$ of the protein backbone in its free and complex form over the

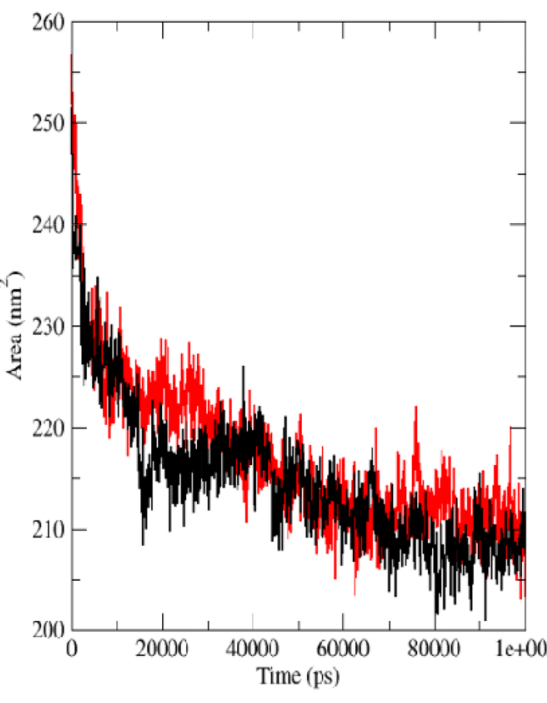

d

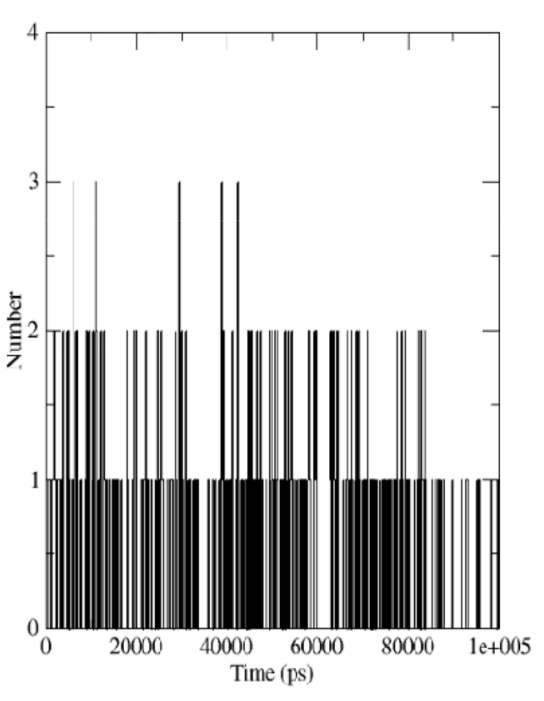

e entire simulation time. The ordinate is $R_{\mathrm{g}}(\mathrm{nm})$, and the abscissa is the time (ps) interval. d SASA is indicated, where ordinate is SASA $(\mathrm{nm})$, and the abscissa is time (ps). e Hydrogen bonds occurring over the time of simulation between protein and ligand. Note: Red: COX-2 protein; Black: COX-2 protein and $\mathbf{3 b}$ ligand complex
Table 6 Binding free energy calculations of ligand $3 \mathrm{~b}$ with COX-1 and COX-2

\begin{tabular}{lccccc}
\hline $\begin{array}{l}\text { Types of binding free } \\
\text { energies }\end{array}$ & \multicolumn{2}{l}{ COX-1 with 3b ligand complex } & & \multicolumn{2}{c}{ COX-2 with 3b ligand complex } \\
\cline { 2 - 3 } \cline { 5 - 6 } & Value $(\mathrm{kj} / \mathrm{mol})$ & $\begin{array}{l}\text { Standard deviation } \\
(\mathrm{kj} / \mathrm{mol})\end{array}$ & & Value $(\mathrm{kj} / \mathrm{mol})$ & $\begin{array}{l}\text { Standard } \\
\text { deviation }(\mathrm{kj} / \\
\text { mol })\end{array}$ \\
\hline van der waals & -55.165 & \pm 59.959 & -44.007 & \pm 47.787 \\
Electrostatic & -2.766 & \pm 4.658 & & -3.008 & \pm 8.493 \\
Polar solvation & 16.300 & \pm 20.413 & & 18.405 & \pm 22.805 \\
SASA & -4.325 & \pm 7.232 & & -4.111 & \pm 5.130 \\
Binding energy & -45.956 & \pm 47.919 & & -32.720 & \pm 34.129 \\
\hline
\end{tabular}


manner among ligands and their corresponding protein complexes. It was evident from the RMSD plot (Fig. 3a and 4a) that all the ligand-protein complexes attained stability approximately after $10.0 \mathrm{~ns}$ time and remaining showed a stable trajectory reaching equilibrium between 0.30 and $0.45 \mathrm{~nm}$. The structural flexibility represented as the RMSD range is being reserved as a complex with the ligand much better than its free form. Proteins unbound to their ligands demonstrate stable trajectories, whereas the bound counterparts attain equilibrium right after the fluctuations at the initial stages. The residue-wise fluctuations can be evident from the RMSF plot (Fig. 3b and 4b), representing the rigidified amino acids forming the complex in comparison with the innate protein. The RMSF plot depicts the highest fluctuation at N-terminal and loop region (200-300th residues). Yet minimal fluctuations were observed after that, indicating the stable interaction of the ligand with both the proteins throughout the simulation. The radius of gyration $\left(R_{\mathrm{g}}\right)$ obtained after consideration of the central axis of rotation and the varied masses acquired from the root-mean-square distance calculation. The $R_{\mathrm{g}}$ plot (Fig. $3 \mathrm{c}$ and $4 \mathrm{c}$ ) considers parameters such as shape, folding, and capability during each step of the whole trajectory throughout the simulation. All the entries, including proteins and their corresponding ligand complexes, exhibit a similar pattern of $R_{\mathrm{g}}$ value, with a deviation ranging from 2.30 to $2.45 \mathrm{~nm}$. Solvent accessible surface area (SASA) evaluated the hydrophobic core area between protein-ligand complexes (Figs. $3 \mathrm{~d}$ and $4 \mathrm{~d}$ ). Consistent SASA values were observed, typically fluctuating between 205 and $250 \mathrm{~nm}^{2}$. H-bonds appeared throughout the simulation period considered from both ligands and protein during the analysis and plotted accordingly (Fig. 3e and 4e). The docking results reveal that overall, the total number of H-bonds were consistent with only a few bonds broken and reconstructed simultaneously. The highest number of hydrogen bonds reached during the simulation was 4 for COX-1 and $3 \mathrm{~b}$ complex, and 3 for COX-2 and $\mathbf{3 b}$ complex.

\section{Binding free energy calculations}

To assess the extent of binding exhibited by the compounds to the protein, the binding free energy was evaluated to demonstrate the energy released during the formation of a complex between the protein and its ligand. Binding energy with a more negative value is preferred as it details the formation of a stable complex. In this scenario, the binding free energy was calculated in terms of van der Waals electrostatic, polar solvation, SASA, and binding interaction energies. By virtue of different binding free energies, ligand $\mathbf{3 b}$ could form the stable complex with both the proteins, i.e., COX-1 and COX-2 (Table 6). In addition, the standard deviation was calculated, representing the deviation of all the ligands from the mean values of van der Waals, electrostatic, polar solvation, SASA, and binding energy. A lower standard deviation shows that the values tend to be closer to the mean (or expected value) of the data, while a high standard deviation indicates that the values are spread out over a broader range. In this study, the standard deviation indicates that the values for ligand $\mathbf{3 b}$ with both COX-1 and COX-2 were nearing the mean value, indicating a stable interaction of the compound with the target proteins.

\section{Conclusion}

In conclusion, the current investigation demonstrated that the development of $\mathrm{Pd}(\mathrm{OH})_{2}$ catalyzed system for the Suzuki-Miyaura cross-coupling reaction of aryl boronic acids with aryl bromides using predominantly ethanol as a solvent under moderate conditions. Further, all the samples were evaluated for their anti-inflammatory and analgesic activities. The obtained data revealed that compound $\mathbf{3 b}$ containing two fluoro and one $\mathrm{CF}_{3}$ group exhibit a potent antiinflammatory activity compared with that of the standard drug. Furthermore, the same molecule $\mathbf{3 b}$ demonstrated a considerable analgesic effect in acetic acid-induced writhing and thermal pain. The findings demonstrated a link between the analgesic and anti-inflammatory properties of custommade compounds 3a-j. Both in vivo and in silico COX inhibition studies depict compound $\mathbf{3 b}$ as the potent inhibitor. The fluoro groups present in both the rings of the molecule could be attributed for this significant COX-1 and COX-2 inhibition. Compound $3 \mathrm{~b}$ was predicted with considerable stability and molecular interaction during molecular dynamics simulation studies. In addition, it was predicted to form a bond with the proteins majorly using van der Waals forces.

\section{Materials and methods}

\section{Chemistry}

The reagents and solvents were purchased from commercial suppliers and used without further purification. For thinlayer chromatography (TLC), Merck pre-coated TLC plates (Silica gel $60 \mathrm{~F}_{254}$ ) were employed. The melting points were determined on a Thomas Hoover capillary melting point apparatus with a digital thermometer and are uncorrected. The NMR spectra were recorded in DMSO- $\mathrm{d}_{6}$ solutions at $25^{\circ} \mathrm{C}$ on a Bruker $400 \mathrm{MHz}$ NMR spectrophotometer. The chemical shifts expressed in ppm were relative to tetramethylsilane (TMS). The mass spectra were obtained with a VG70-70H spectrophotometer, and important fragments were given with the relative intensities in brackets. 


\section{Synthesis of substituted biphenyls}

Substituted phenylboronic acids $\mathbf{1 a - b}(0.5 \mathrm{~g}, 3.57 \mathrm{mmol})$ were added to a solution of substituted bromobenzene 2a-e $(0.72 \mathrm{~g}, 3.57 \mathrm{mmol})$ in a mixture of ethanol/water (3:1, $10 \mathrm{~mL})$. Potassium phosphate $(2.28 \mathrm{~g}, 10.72 \mathrm{mmol})$ was added and degasified the mass with nitrogen for 10-15 min. Palladium hydroxide (50 mg, $0.036 \mathrm{mmol}$ ) was added and degasified with nitrogen for $10 \mathrm{~min}$ and heated to $65^{\circ} \mathrm{C}$ for $2-3 \mathrm{~h}$. The reaction completion was confirmed by TLC, and the reaction mass was concentrated to remove ethanol at $50{ }^{\circ} \mathrm{C}$, cooled to $25^{\circ} \mathrm{C}$, and the mass was diluted with water $(10 \mathrm{~mL})$ and extracted twice with dichloromethane $(20 \mathrm{~mL})$. The combined organic layer was washed with brine, dried over sodium sulfate, filtered, and concentrated to yield the crude product. The product was purified by a filter column using hexane to yield the pure product (Scheme 1, Table 7)

\section{3a. 2-Fluoro-4'-nitrobiphenyl}

IR (Nujol): $1350-1320 \mathrm{~cm}^{-1}\left(-\mathrm{NO}_{2}\right.$, Sym). ${ }^{1} \mathrm{H}$ NMR $\left(400 \mathrm{MHz}, \mathrm{DMSO}-\mathrm{d}_{6}, \mathrm{ppm}\right): \delta 7.19(t, J=8.0 \mathrm{~Hz}, 1 \mathrm{H})$, $7.30(t, J=8.0 \mathrm{~Hz}, 1 \mathrm{H}), 7.41(d, J=8.0 \mathrm{~Hz}, 1 \mathrm{H}), 7.49(d$, $J=8.0 \mathrm{~Hz}, 1 \mathrm{H}), 7.75(d, J=8.0 \mathrm{~Hz}, 2 \mathrm{H}), 8.33(d, J=8.0 \mathrm{~Hz}$, $2 \mathrm{H}) .{ }^{13} \mathrm{C}$ NMR (100 MHz, DMSO-d 6 , ppm): $\delta$ 116.0, 121.6(2), 124.9, 128.8(2), 129.3, 129.5, 131.3, 142.6, 147.3, $158.8\left(d d, J_{\mathrm{FC}}=245 \mathrm{~Hz}\right)$. LC-MS m/z 218(M+1). Anal. Calcd. For $\mathrm{C}_{12} \mathrm{H}_{8} \mathrm{FNO}_{2}$ (217.05): C, 66.36; H, 3.71; N, 6.45. Found: C, 66.34; H, 3.76; N, 6.48\%.

\section{3b. 2,4'-Difluoro-3'-(trifluoromethyl) biphenyl}

${ }^{1} \mathrm{H}$ NMR (400 MHz, DMSO-d $\left.\mathrm{d}_{6}, \mathrm{ppm}\right): \delta 7.23(t, J=8.0 \mathrm{~Hz}$, $2 \mathrm{H}), 7.45(t, J=8.0 \mathrm{~Hz}, 1 \mathrm{H}), 7.68(d, J=8.0 \mathrm{~Hz}, 2 \mathrm{H}), 7.74$ $(d, J=8.0 \mathrm{~Hz}, 1 \mathrm{H}), 7.84(s, 1 \mathrm{H}) .{ }^{13} \mathrm{C}$ NMR $(100 \mathrm{MHz}$, DMSO-d $\left._{6}, \mathrm{ppm}\right): \delta 113.7\left(q, J_{\mathrm{FC}}=272.1 \mathrm{~Hz}\right), 116.1,116.3$, 119.2, 124.8, 128.6, 129.4, 129.6, 131.4, 132.5, 132.9, 156.6 $\left(\mathrm{dd}, J_{\mathrm{FC}}=240 \mathrm{~Hz}\right), 158.9\left(\mathrm{dd}, J_{\mathrm{FC}}=242 \mathrm{~Hz}\right) . \mathrm{LC}-\mathrm{MS} \mathrm{m} / \mathrm{z}$ 259(M+1). Anal. Calcd. For $\mathrm{C}_{13} \mathrm{H}_{7} \mathrm{~F}_{5}$ (258.05): C, 60.48; H, 2.73. Found: C, 60.46; H, $2.78 \%$.

\section{3c. 2,4'-Difluoro-3'-(trifluoromethoxy)biphenyl}

${ }^{1} \mathrm{H}$ NMR (400 MHz, DMSO-d $\left.{ }_{6}, \mathrm{ppm}\right): \delta 7.26(t, J=8.0 \mathrm{~Hz}$, $2 \mathrm{H}), 7.45(d, J=8.0 \mathrm{~Hz}, 2 \mathrm{H}), 7.49(s, 1 \mathrm{H}) .7 .52(d$, $J=8.0 \mathrm{~Hz}, 2 \mathrm{H}) .{ }^{13} \mathrm{C}$ NMR $\left(100 \mathrm{MHz}\right.$, DMSO-d $\left.{ }_{6}, \mathrm{ppm}\right): \delta$ $113.4,116.2$, 117.0, 121.6, $121.8\left(q, J_{\mathrm{FC}}=278 \mathrm{~Hz}\right), 124.8$, $129.3,129.8,131.3,133.3,150.0,151.0,\left(\mathrm{dd}, J_{\mathrm{FC}}=240 \mathrm{~Hz}\right)$, $158.6\left(\mathrm{dd}, J_{\mathrm{FC}}=241.5 \mathrm{~Hz}\right)$. LC-MS m/z 275(M+1). Anal. Calcd. For $\mathrm{C}_{13} \mathrm{H}_{7} \mathrm{~F}_{5} \mathrm{O}$ (274.05): C, 56.95; H, 2.57. Found: $\mathrm{C}, 56.93 ; \mathrm{H}, 2.55 \%$.

\section{3d. 2,2'-Difluoro-3-nitrobiphenyl}

IR (Nujol): $1550-1480 \mathrm{~cm}^{-1}\left(-\mathrm{NO}_{2}\right.$, Asym). ${ }^{1} \mathrm{H}$ NMR (400 MHz, DMSO-d $\left.{ }_{6}, \mathrm{ppm}\right): \delta 7.21(d, J=8.0 \mathrm{~Hz}, 1 \mathrm{H})$, $7.32(t, J=8.0 \mathrm{~Hz}, 2 \mathrm{H}), 7.48(d, J=8.0 \mathrm{~Hz}, 2 \mathrm{H}), 7.72$ $(d, J=8.0 \mathrm{~Hz}, 1 \mathrm{H}), 8.15(d, J=8.0 \mathrm{~Hz}, 1 \mathrm{H}) .{ }^{13} \mathrm{C} \mathrm{NMR}$ (100 MHz, DMSO-d 6 , ppm): $\delta 116.1,121.6,124.8$, 125.7, 129.1, 129.7, 131.4, 132.3, 135.5, 135.9, 156.1 (dd, $\left.J_{\mathrm{FC}}=240 \mathrm{~Hz}\right), 158.8\left(\mathrm{dd}, J_{\mathrm{FC}}=245.8 \mathrm{~Hz}\right) . \mathrm{LC}-\mathrm{MS} \mathrm{m} / \mathrm{z} 236$ $(\mathrm{M}+1)$. Anal. Calcd. For $\mathrm{C}_{12} \mathrm{H}_{7} \mathrm{~F}_{2} \mathrm{NO}_{2}$ (235.05): C, 61.28; H, 3.00; N, 5.96. Found: C, 61.25; H, 3.03; N, 5.94\%.

\section{3e. 2,2'-Difluoro-5-methoxybiphenyl}

${ }^{1} \mathrm{H}$ NMR (400 MHz, DMSO-d $\left.{ }_{6}, \mathrm{ppm}\right): \delta 3.74(s, 3 \mathrm{H}), 6.71(d$, $J=8.0 \mathrm{~Hz}, 1 \mathrm{H}), 6.92(d, J=8.0 \mathrm{~Hz}, 2 \mathrm{H}), 7.20(t, J=8.0 \mathrm{~Hz}$, $2 \mathrm{H}), 7.47(d, J=8.0 \mathrm{~Hz}, 1 \mathrm{H}),{ }^{13} \mathrm{C}$ NMR $(100 \mathrm{MHz}$, DMSO$\left.\mathrm{d}_{6}, \mathrm{ppm}\right): \delta 55.8,113.2,114.9,116.0,117.1,124.8,129.3$, $129.9,131.4,132.5,151.2\left(\mathrm{dd}, J_{\mathrm{FC}}=240 \mathrm{~Hz}\right), 156.8,158.5$ $\left(\mathrm{dd}, J_{\mathrm{FC}}=242 \mathrm{~Hz}\right)$. LC-MS m/z $221(\mathrm{M}+1)$. Anal. Calcd. For $\mathrm{C}_{13} \mathrm{H}_{10} \mathrm{~F}_{2} \mathrm{O}$ (220.07): C, 70.90; H, 4.58. Found: $\mathrm{C}, 70.93$; $\mathrm{H}, 4.55 \%$.

\section{3f. 2-Methoxy-4'-nitrobiphenyl}

IR (Nujol): $1355-1330 \mathrm{~cm}^{-1}\left(-\mathrm{NO}_{2}\right.$, Sym). ${ }^{1} \mathrm{H}$ NMR $\left(400 \mathrm{MHz}\right.$, DMSO-d $\left.{ }_{6}, \mathrm{ppm}\right): \delta 3.71(s, 3 \mathrm{H}), 7.15(t$, $J=8.0 \mathrm{~Hz}, 1 \mathrm{H}), 7.28(t, J=8.0 \mathrm{~Hz}, 1 \mathrm{H}), 7.35(d, J=8.0 \mathrm{~Hz}$, $1 \mathrm{H}), 7.42(d, J=8.0 \mathrm{~Hz}, 1 \mathrm{H}) .7 .67(d, J=8.0 \mathrm{~Hz}, 2 \mathrm{H}), 8.16$ $(d, J=8.0 \mathrm{~Hz}, 2 \mathrm{H}) .{ }^{13} \mathrm{C}$ NMR $\left(100 \mathrm{MHz}, \mathrm{DMSO}^{-\mathrm{d}_{6}}, \mathrm{ppm}\right): \delta$ 56.1, 114.8, 121.6(2), 121.8, 125.4, 128.2 (2), 128.5, 128.9, 142.4, 148.2, 157.6. LC-MS m/z $230(\mathrm{M}+1)$. Anal. Calcd. For $\mathrm{C}_{13} \mathrm{H}_{11} \mathrm{NO}_{3}$ (229.07): C, 68.11; H, 4.84; N, 6.11. Found: C, 68.14; H, 4.87; N, 6.14\%.

\section{3g. 4'-Fluoro-2-methoxy-3'-(trifluoromethyl)biphenyl}

${ }^{1} \mathrm{H}$ NMR (400 MHz, DMSO-d 6 , ppm): $\delta 3.81(s, 3 \mathrm{H}), 7.13(t$, $J=8.0 \mathrm{~Hz}, 1 \mathrm{H}), 7.22(t, J=8.0 \mathrm{~Hz}, 2 \mathrm{H}), 7.39(d, J=8.0 \mathrm{~Hz}$, $1 \mathrm{H}), 7.48(d, J=8.0 \mathrm{~Hz}, 1 \mathrm{H}) .7 .81(d, J=8.0 \mathrm{~Hz}, 2 \mathrm{H})$, $7.95(d, J=8.0 \mathrm{~Hz}, 1 \mathrm{H}) .{ }^{13} \mathrm{C}$ NMR $\left(100 \mathrm{MHz}, \mathrm{DMSO}_{-} \mathrm{d}_{6}\right.$, ppm): $\delta 56.1,113.6\left(q, J_{\mathrm{FC}}=245 \mathrm{~Hz}\right), 114.8,116.4,119.2$, 121.5, 125.6, 128.4, 128.6, 128.9, 132.4, 132.7, 156.9 (dd, $\left.J_{\mathrm{FC}}=240 \mathrm{~Hz}\right), 157.7$. LC-MS m/z $270(\mathrm{M}+1)$. Anal. Calcd. For $\mathrm{C}_{14} \mathrm{H}_{10} \mathrm{~F}_{4} \mathrm{O}$ (270.05): C, 62.23; $\mathrm{H}, 3.73$. Found: $\mathrm{C}, 62.25$; $\mathrm{H}, 3.76 \%$.

\section{3f. 4'-Fluoro-2-methoxy-3'-(trifluoromethoxy)biphenyl}

${ }^{1} \mathrm{H}$ NMR (400 MHz, DMSO-d 6 , ppm): $\delta 3.76$ (s, 3H), 7.23 $(t, J=8.0 \mathrm{~Hz}, 2 \mathrm{H}), 7.28(d, J=8.0 \mathrm{~Hz}, 1 \mathrm{H}), 7.31(s, 1 \mathrm{H})$, $7.37(d, J=8.0 \mathrm{~Hz}, 2 \mathrm{H}), 7.52(d, J=8.0 \mathrm{~Hz}, 1 \mathrm{H}) .{ }^{13} \mathrm{C} \mathrm{NMR}$ 
Scheme 1 Synthesis of biaryl analogs

Table 7 Suzuki-Miyaura coupling of an aryl halide with aryl boronic acid $\mathbf{3 a} \mathbf{a} \mathbf{j}$

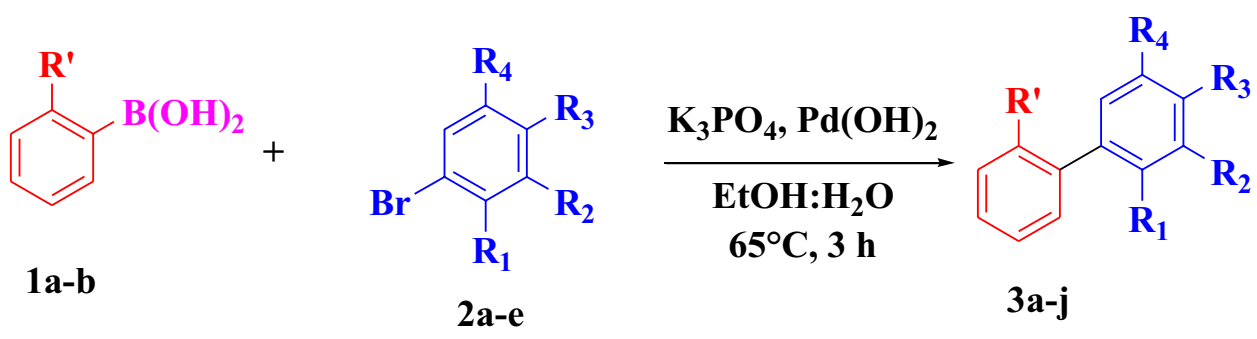

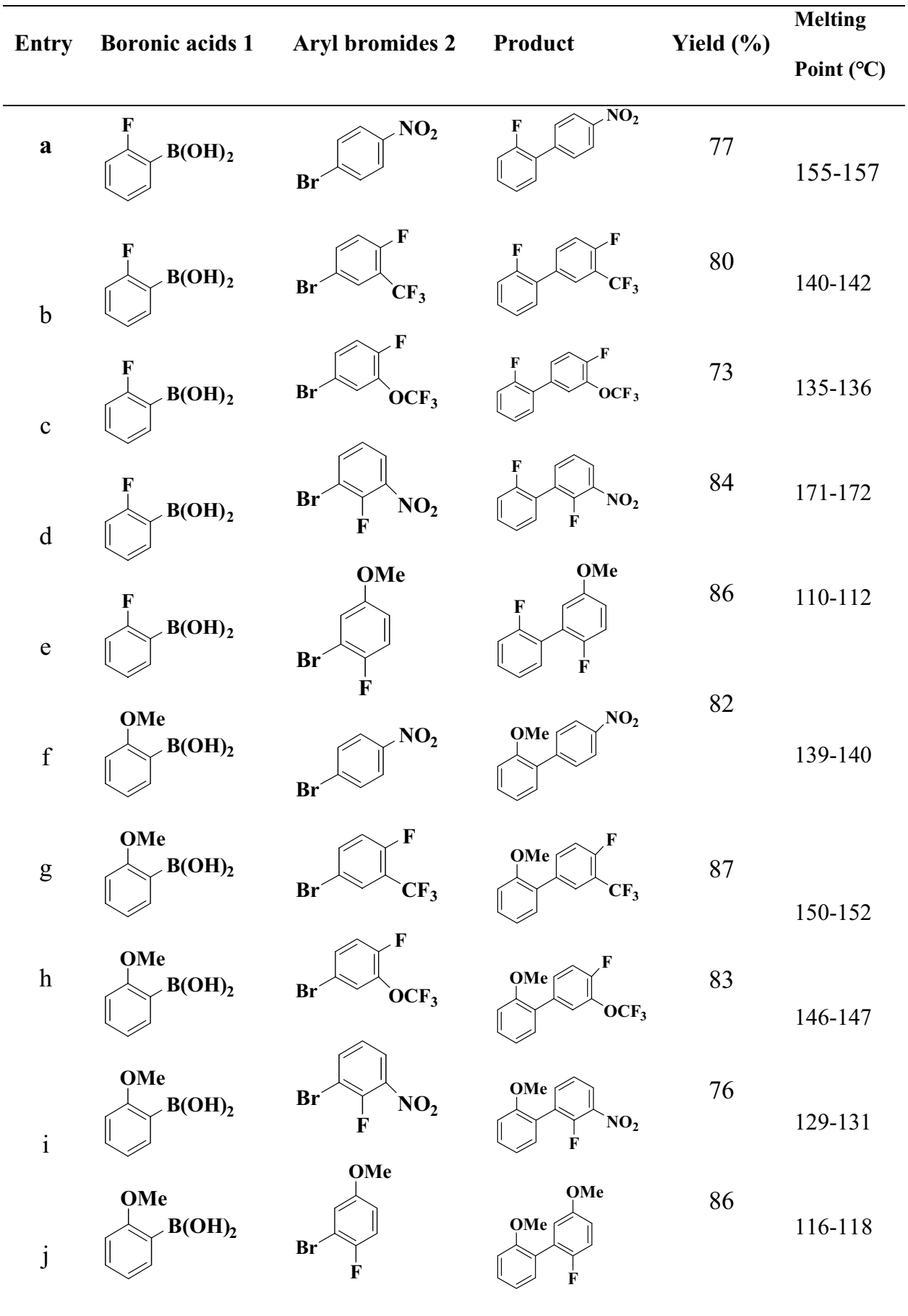


(100 MHz, DMSO-d 6 , ppm): $\delta 56.2,113.6,114.8,117.0$, $121.5,121.7,121.9\left(q, J_{\mathrm{FC}}=270 \mathrm{~Hz}\right), 125.6,128.5,128.7$, $133.2,150.1,151.0\left(\mathrm{dd}, J_{\mathrm{FC}}=248.1 \mathrm{~Hz}\right), 157.9$. LC-MS $\mathrm{m} / \mathrm{z} 287(\mathrm{M}+1)$. Anal. Calcd. For $\mathrm{C}_{14} \mathrm{H}_{10} \mathrm{~F}_{4} \mathrm{O}_{2}$ (286.06): $\mathrm{C}$, 58.75 ; H, 3.52. Found: C, 58.77; H, 3.55\%.

\section{3i. 2-Fluoro-2'-methoxy-3-nitrobiphenyl}

IR (Nujol): $1355-13,250 \mathrm{~cm}^{-1}$ (-NO $\mathrm{NO}_{2}$, Asym). ${ }^{1} \mathrm{H}$ NMR $\left(400 \mathrm{MHz}, \mathrm{DMSO}-\mathrm{d}_{6}, \mathrm{ppm}\right): \delta 3.65(s, 3 \mathrm{H}), 6.89(d$, $J=8.0 \mathrm{~Hz}, 1 \mathrm{H}), 7.35(t, J=8.0 \mathrm{~Hz}, 2 \mathrm{H}), 7.37(d, J=8.0 \mathrm{~Hz}$, $1 \mathrm{H}), 7.40(d, J=8.0 \mathrm{~Hz}, 1 \mathrm{H}), 7.77(d, J=8.0 \mathrm{~Hz}, 1 \mathrm{H}), 8.11$ $(d, J=8.0 \mathrm{~Hz}, 1 \mathrm{H}) .{ }^{13} \mathrm{C}$ NMR $\left(100 \mathrm{MHz}\right.$, DMSO-d $\left.\mathrm{d}_{6}, \mathrm{ppm}\right): \delta$ 56.3, 114.8, 121.6, 121.8, 125.8, 125.9, 128.6, 128.9, 131.2, $135.5,135.9,156.2\left(\mathrm{dd}, J_{\mathrm{FC}}=245 \mathrm{~Hz}\right), 158.1 . \mathrm{LC}-\mathrm{MS} \mathrm{m} / \mathrm{z}$ $248(\mathrm{M}+1)$. Anal. Calcd. For $\mathrm{C}_{13} \mathrm{H}_{10} \mathrm{FNO}_{3}$ (247.06): $\mathrm{C}$, 63.16; H, 4.08; N, 5.67. Found: C, 63.18; H, 4.05; N, 5.64\%.

\section{3j. 2-Fluoro-2',5-dimethoxybiphenyl}

${ }^{1} \mathrm{H}$ NMR (400 MHz, DMSO-d 6 , ppm): $\delta 3.69(s, 6 \mathrm{H}), 6.78(d$, $J=8.0 \mathrm{~Hz}, 1 \mathrm{H}), 6.97(s, 1 \mathrm{H}), 7.11(t, J=8.0 \mathrm{~Hz}, 2 \mathrm{H}), 7.23(d$, $J=8.0 \mathrm{~Hz}, 1 \mathrm{H}), 7.51(d, J=8.0 \mathrm{~Hz}, 1 \mathrm{H}), 7.61(d, J=8.0 \mathrm{~Hz}$, 1H). ${ }^{13} \mathrm{C}$ NMR (100 MHz, DMSO-d $\left.\mathrm{d}_{6}, \mathrm{ppm}\right): \delta 55.8,56.2$, 113.2, 114.8, 114.9, 117.0, 121.6, 125.8, 128.6, 128.9, 132.3, $151.1\left(\mathrm{dd}, J_{\mathrm{FC}}=272.1 \mathrm{~Hz}\right), 157.0,150.1 . \mathrm{LC}-\mathrm{MS} \mathrm{m} / \mathrm{z} 233$ $(\mathrm{M}+1)$. Anal. Calcd. For $\mathrm{C}_{14} \mathrm{H}_{13} \mathrm{FO}_{2}$ (232.09): C, 72.40; H, 5.64. Found: $\mathrm{C}, 72.43 ; \mathrm{H}, 5.66 \%$.

\section{Pharmacology}

\section{Biological evaluation, animal models, and ethics}

For in vivo biological assay, adult male Swiss albino mice (20-25 g) and Wistar rats (150-175 g) were obtained and maintained under controlled conditions at a temperature of $26 \pm 1{ }^{\circ} \mathrm{C}$ and relative humidity of 50-90 percent, with free access to standard pellet meal and tap water during the biological assay. All the animals were housed for a week before the experiment to acclimatize to the new experimental environment. Further, all the experimental techniques and animal handling were carried out following the rules of the Farooqia Pharmacy College's Research Ethical Committee in Mysuru.

\section{COX-1 and COX-2 in vitro inhibitory activity}

The colorimetric enzyme immune assay $[1,28]$ was used to test the efficiency of the title compounds $\mathbf{3 a}-\mathbf{j}$ in inhibiting COX-1 and COX- 2 enzymes. The COX inhibitor screening assay kit [1,29] was used to determine the inhibitory activity of the synthesized compounds against COX-1 and COX-2.

\section{Anti-inflammatory in vivo activity}

The anti-inflammatory performance activity of the newly synthesized compounds $\mathbf{3 a - j}$ was assessed adopting the in vivo formalin-induced rat foot paw edema model reported by Zabiulla et al., and Swarup et al. [1, 30].

\section{Analgesic activity: acetic acid-induced writhing test}

The acetic acid-induced writhing test was performed according to the earlier described method by Zabiulla et al., Koster, et al., and Arrigoni-Martelli et al. [1,31]

\section{Hot plate latency test}

The hot plate latency test was carried out as described previously by Zabiulla et al., and Fakhr et al. [1, 32]

\section{Molecular docking studies of the lead compound $3 \mathrm{~b}$}

The synthesized compounds were virtually sketched for docking operation using the SERFLEXDOCK program present in the SYBYL-X 2.1.1 software package (Tripose, USA), and necessary calculations were performed as per Mandal et al. [26]. The overall procedure of the DOCKING program includes ligand preparation, protein preparation, Protomol generation, and docking of ligands. The docking protocol was adapted and validated using a comparison of the binding angles of the co-crystallized ligand with the target protein COX-1 and COX-2(PDB ID: 1EGG and 4M11) before and after the docking study. The software package SYBYL-X 2.1.1 was employed to sketch the molecular area of the synthesized compounds. They were prepared and stored using the module for ligand preparation, converted to 3D form along with minimization of energy using MMFF94s and addition of charges using the Gasteiger-Huckel method. Hydrogens and omitted amino acids from the PDB-retrieved protein were added, water molecules were eliminated, and charges were applied to prepare the protein for docking studies. Energy minimization was carried out with 1000 iterations of the conjugate gradient method with $1.0 \mathrm{kcal} / \mathrm{mol}$ as the convergence criteria. The biopolymer preparation wizard in the SYBYL-X 2.1.1 software was employed to carry out the steps in the docking studies for which the active site was located using Protomol generation. Protomol provides an ensemble of various amino acids and their corresponding intermolecular interactions with the target protein, and the same has been used to prepare the binding of a protein and the co-crystallized ligand in its cavity. Further, this GEOM mode was used to interact with the protein and its ligand producing 20 conformers for each ligand to identify the most 
stable conformer. The respective docking scores in terms of Total score, Crash score, and Polar score were obtained.

\section{MD simulation study}

MD simulation study was carried out using the native protein structures (PDB ID: 1EGG and 4M11) with ligand structure using innate and docked forms on GROMACS 5.1.5 platform[33], implemented with CHARMM27 allatom force field[34]. Using the SwissParam server (http:// www.swissparam.ch/) of the CHARMM all atoms force field, the topology files were prepared externally. The van der Waal interactions were calculated with a distance cutoff of $1.0 \mathrm{~nm}$. The long-range electrostatics having a cutoff of $1 \mathrm{~nm}$ for columbic interactions were handled using Partial Mesh Ewald (PME) summation. Counter ions were included for the requirement of the electro-neutrality condition of the system. TIP3P water model was employed for solvating the system and simulated in a triclinic box by placing the protein atoms $1.0-1.5 \mathrm{~nm}$ away from the wall of the box dimensions maintaining periodic boundary conditions. The steepest descent algorithm was employed for energy minimization of the structures with a tolerance of $1000 \mathrm{~kJ} /$ $\mathrm{mol} / \mathrm{nm}$. The system was equilibrated by applying position restraints on the complex and performing simulations using canonical NVT ensembles followed by NPT ensembles, run for $200 \mathrm{ps}$ each at a temperature of $300 \mathrm{~K}$ and 1 bar pressure. A coupling constant of $0.1 \mathrm{ps}$ was used for temperature coupling performed using velocity rescaling as per Maxwell distribution. For performing temperature-pressure coupling, a coupling constant of 2 ps was applied using the extended ensemble Parrinello-Rahman algorithm. The equilibrated system was then subjected to $10 \mathrm{~ns}$ of production run [26] with a $2 \mathrm{fs}$ time step integration. The trajectories were saved every 500 steps and analyzed using GROMACS analysis tools and the XMGRACE-5.1.22 program (http://plasmagate.weizmann.ac.il/Grace/).

\section{Binding free energy calculations}

Further, using the bonded and non-bonded interactions polar and non-polar solvation from the molecular dynamic's trajectories, binding free energy ( $\Delta \mathrm{G}$ binding) for both BCD-6 and Remdesivir over the simulation time was calculated using the molecular mechanics/Poisson-Boltzmann surface area (MM-PBSA) approach. Meanwhile, a GROMACS feature known as g_mmpbsa [33] with the MmPBSADecomp. py [34] script was employed to evaluate the binding free energy. The last $50 \mathrm{~ns}$ were used to compute the accurate $\Delta \mathrm{G}$ with dt 1000 frames. The binding free energy is thus calculated based on Eq. (1) and (2).
$\Delta G_{\text {binding }}=G_{\text {complex }}-\left(G_{\text {protein }}+G_{\text {ligand }}\right)$

$$
\begin{aligned}
\Delta G= & \Delta E_{\mathrm{MM}}+\Delta G_{\text {solvation }}-T \Delta S=\Delta E_{(\text {bonded }+ \text { non - bonded })} \\
& +\Delta G_{(\text {polar+non - polar })}-T \Delta S
\end{aligned}
$$

Supplementary Information The online version contains supplementary material available at https://doi.org/10.1007/s13738-021-02460-0.

Acknowledgements Dr. Shaukath Ara Khanum appreciates the financial support provided by the Government of Karnataka, Vision Group on Science and Technology, Bangalore [VGST/CISSE/2012-13/282]. Dr. Lakshmi Ranganatha V gratefully acknowledges NIE Management, Mysuru, for their encouragement and constant support to carry out the research work.

\section{References}

1. A.R. Gulnaz, Y.H.E. Mohammed, S.A. Khanum, Design, synthesis and molecular docking of benzophenone conjugated with oxadiazole sulphur bridge pyrazole pharmacophores as anti inflammatory and analgesic agents. Bioorg. Chem. 92, 103220 (2019)

2. T. Rottiers, B. Van der Burggen, L. Pinoy, Production of salicylic acid in a three compartment bipolar membrane electrodialysis configuration. J. Ind. Eng. Chem. 54, 190-199 (2017)

3. J.L. Wallace, Prostaglandins, NSAIDs, and gastric mucosal protection: why doesn't the stomach digest itself? Physiol. Rev. 88, 1547-1565 (2008)

4. K.F. Tempero, V.J. Cirillo, S.L. Steelman, Diflunisal: a review of pharmacokinetic and pharmacodynamic properties, drug interactions, and special tolerability studies in humans. Br. J. Clin. Pharmacol. 4, 31S (1977)

5. F.H. Al-Ostoot, S. Grisha, Y.H.E. Mohammed, H.K. Vivek, S.A. Khanum, Molecular docking and synthesis of caffeic acid analogous and its anti-inflammatory, analgesic and ulcerogenic studies. Bioorg. Med. Chem. Lett. 33, 127743 (2021)

6. S.A. Khanum, S. Shashikanth, A. Firdouse, Synthesis of some newer analogues of substituted dibenzoyl phenol as potent antiinflammatory agents. Bioorg. Med. Chem. Lett. 14, 5351-5355 (2004)

7. S.A. Khanum, N.F. Khanum, M. Shashikanth, Synthesis and antiinflammatory activity of 2-aryloxy methyl oxazolines. Bioorg. Med. Chem. Lett. 18, 4597-4601 (2008)

8. F.H. Al-Ostoot, D.V. Geetha, Y.H.E. Mohammed, P. Akhileshwari, M.A. Sridhar, S.A. Khanum, Design-based synthesis, molecular docking analysis of an anti-inflammatory drug, and geometrical optimization and interaction energy studies of an indole acetamide derivative. J. Mol. Struct. 1202, 127244 (2020)

9. J. Wang, H. Chen, L. Kong, F. Wang, Y. Lan, X. Li, Enantioselective and diastereoselective $\mathrm{C}-\mathrm{H}$ alkylation of benzamides: synergized axial and central chirality via a single stereodetermining step. ACS Catal. 11, 9151-9158 (2021)

10. A. Suzuki, Recent advances in the cross-coupling reactions of organoboron derivatives with organic electrophiles, 1995-1998. J. Organomet. Chem. 576, 147-168 (1999)

11. T.O. Ronson, R.J.K. Taylor, I.J.S. Fairlamb, Palladium-catalysed macrocyclisations in the total synthesis of natural products. Tetrahedron 7, 989-1009 (2015) 
12. G. Bringmann, T. Gulder, T.A.M. Gulder, M. Breuning, Atroposelective total synthesis of axially chiral biaryl natural products. Chem. Rev. 111, 563-639 (2011)

13. F.-X. Felpin, S. Sengupta, Biaryl synthesis with arenediazonium salts: cross-coupling, $\mathrm{CH}$-arylation and annulation reactions. Chem. Soc. Rev. 48, 1150-1193 (2019)

14. T. Borkowski, W. Zawartka, P. Pospiech, U. Mizerska, A.M. Trzeciak, M. Cypryk, W. Tylus, Reusable functionalized polysiloxanesupported palladium catalyst for Suzuki-Miyaura cross-coupling. J. Catal. 282, 270-277 (2011)

15. R. Ricciardi, J. Huskens, M. Holtkamp, U. Karst, W. Verboom, Dendrimer-encapsulated palladium nanoparticles for continuousflow suzuki-miyaura cross-coupling reactions. ChemCatChem 7 , 936-942 (2015)

16. F. Guo, R. Zhou, Z. Jiang, W. Wang, H. Fu, X. Zheng, H. Chen, R. Li, N, N, N', N'-tetra (diphenylphosphinomethyl) pyridine-2, 6-diamine/palladium catalyzed Suzuki-Miyaura coupling of aryl and heteroaryl halides. Catal. Commun. 66, 87-90 (2015)

17. A.V. Gaikwad, A. Holuigue, M.B. Thathagar, J.E. ten Elshof, G. Rothenberg, Ion-and atom-leaching mechanisms from palladium nanoparticles in cross-coupling reactions. Chem. Eur. J. 13, 6908$6913(2007)$

18. K. Wang, T. Yi, X. Yu, X. Zheng, H. Fu, H. Chen, R. Li, Palladium-catalyzed Suzuki-Miyaura coupling with aryl and heteroaryl bromides using $\mathrm{N}, \mathrm{N}, \mathrm{N}^{\prime}, \mathrm{N}^{\prime}$-tetra (diphenylphosphinomethyl)-1, 2-ethylenediamine. Appl. Organomet. Chem. 26, 342-346 (2012)

19. E.K. Reeves, O.R. Bauman, G.B. Mitchem, S.R. Neufeldt, Solvent Effects on the selectivity of palladium-catalyzed Suzuki-Miyaura couplings. Isr. J. Chem. 60, 406-409 (2020)

20. P.Y. Yeung, C.M. So, C.P. Lau, F.Y. Kwong, A mild and efficient palladium-catalyzed cyanation of aryl chlorides with $\mathrm{K} 4[\mathrm{Fe}(\mathrm{CN})$ 6]. Org. Lett. 13, 648-651 (2011)

21. N.A. Bumagin, V.V. Bykov, Ligandless palladium catalyzed reactions of arylboronic acids and sodium tetraphenylborate with aryl halides in aqueous media. Tetrahedron 53, 14437-14450 (1997)

22. L. Liu, W. Wang, C. Xiao, A simple and efficient protocol for Suzuki coupling reactions of aryl chlorides and aryl bromides in aqueous DMF. J. Organomet. Chem. 749, 83-87 (2014)

23. P.S.S. RamithRamu, K.R. Anilakumar, F.Z.S. Nayakavadi, B.L. Dhananjaya, M.N.N. Prasad, Assessment of nutritional quality and global antioxidant response of banana (Musa sp. CV. Nanjangud Rasa Bale) pseudostemand flower. Pharmacogn. Res. 9(1), S74S83 (2017)
24. S. Ali, N. Rasool, A. Ullah, F.-H. Nasim, A. Yaqoob, M. Zubair, U. Rashid, M. Riaz, Design and synthesis of arylthiophene-2-carbaldehydes via Suzuki-Miyaura reactions and their biological evaluation. Molecules 18, 14711-14725 (2013)

25. H.M. Vinusha, S.P. Kollur, H.D. Revanasiddappa, R. Ramu, P.S. Shirahatti, M.N.N. Prasad, S. Chandrashekar, M. Begum, Preparation, spectral characterization and biological applications of Schiff base ligand and its transition metal complexes. Results Chem. 1, 100012 (2019)

26. S.P. Mandal, A. Garg, P. Prabitha, A.D. Wadhwani, L. Adhikary, B.R.P. Kumar, Novel glitazones as PPAR $\gamma$ agonists: molecular design, synthesis, glucose uptake activity and 3D QSAR studies. Chem. Cent. J. 12, 141 (2018). https://doi.org/10.1186/ s13065-018-0508-0

27. S.M. Patil, R.M. Martiz, R. Ramu, P.S. Shirahatti, A. Prakash, B.R.P. Kumar, N. Kumar, Evaluation of flavonoids from banana pseudostem and flower (quercetin and catechin) as potent inhibitors of $\alpha$-glucosidase: an in silico perspective, J. Biomol. Struct. Dyn. (2021) 1-15

28. P.N.P. Rao, M. Amini, H. Li, A.G. Habeeb, E.E. Knaus, Design, synthesis, and biological evaluation of 6-substituted-3-(4methanesulfonylphenyl)-4-phenylpyran-2-ones: a novel class of diarylheterocyclic selective cyclooxygenase-2 inhibitors. J. Med. Chem. 46, 4872-4882 (2003)

29. M.D. Ferrer, C. Busquets-Cortés, X. Capo, S. Tejada, J.A. Tur, A. Pons, A. Sureda, Cyclooxygenase- 2 inhibitors as a therapeutic target in inflammatory diseases. Curr. Med. Chem. 26, 3225-3241 (2019)

30. A. Swarup, R. Agarwal, S. Malhotra, A.S. Dube, A comparative study of efficacy of gabapentin in inflammation induced neuropathic animal pain models with conventional analgesic diclofenac. Int J Res Med Sci. 4, 1429-1432 (2016)

31. R. Koster, Acetic Acid forAanalgesic Screening, In: Fed Proc, (1959): p. 412

32. I.M.I. Fakhr, M.A.A. Radwan, S. El-Batran, O.M.E. Abd ElSalam, S.M. El-Shenawy, Synthesis and pharmacological evaluation of 2-substituted benzo [b] thiophenes as anti-inflammatory and analgesic agents. Eur. J. Med. Chem. 44, 1718-1725 (2009)

33. R. Kumari, R. Kumar, O.S.D.D. Consortium, A. Lynn, g_mmpbsa A GROMACS tool for high-throughput MM-PBSA calculations. J. Chem. Inf. Model. 54, 1951-1962 (2014)

34. B.R. Miller III, T.D. McGee Jr, J.M. Swails, N. Homeyer, H. Gohlke, A.E. Roitberg, MMPBSA. py: an efficient program for end-state free energy calculations, J. Chem. Theory Comput. 8 (2012) 3314-3321 